\title{
Formulation of Strategy to Face Business Changes in Sales and Distribution of Telecommunication Products (Case Study: Koperasi Telkomsel)
}

\author{
Mujiatno $^{1}$, M. Syamsul Maarif ${ }^{1}$, Yunus Triyonggo ${ }^{1}$ \\ ${ }^{1}$ IPB University, School of Business, Jl. Raya Pajajaran Bogor, Indonesia \\ Corresponding Author: Mujiatno
}

\begin{abstract}
Koperasi Telkomsel (Kisel) as a business of selling and distributing telecommunication products, need to adapt and formulate new strategies in changes of telecommunications sector as a result of customer behavior and the Covid-19 pandemic effects. The aims of this research are to formulate Kisel's strategy, starting from environment analysis, formulate alternative strategy, and create strategy priority in sales and distribution of telecommunication products changes. This research was conducted using qualitative and quantitative research methods with primary data collection techniques from 31 respondents through surveys, interviews, and Focus Group Discussions (FGD), as well as using secondary data from internal data and literature studies. The selection of respondents was carried out deliberately (purposive sampling) considering that the selected respondents have experience and expertise in their fields and have the authority to determine policies and operational decisions. From this research, the results of the identification and analysis of environmental factors were obtained with an Internal Factors Evaluation (IFE) value of 2.74 and an External Factors Evaluation (EFE) of 3.04. These results are in the build \& growth quadrant of IE Matrix with intensive strategies such as market penetration, market development, product development and integration strategies. From the SWOT analysis and QSPM decision-making technique, Kisel's four strategic initiatives and priorities were obtained, such as maintaining and securing existing businesses, strengthening business infrastructure and digital business foundations, strengthening and developing core
\end{abstract}

businesses and expanding non-captive market businesses.

Keywords: Formulation of Strategy, Koperasi

Telkomsel, Telecommunication, SWOT

Analysis, QSPM

\section{INTRODUCTION}

The telecommunications sector is one of the business sectors that is prioritised to carry out activities during the Covid-19 pandemic. This sector is the driving force for the emergence of new adaptations in most industries that are transforming towards digital. The production, transaction and system integration processes that were originally conventional evolve to be completely digital and have encouraged the telecommunications industry sector to continue to develop in the future. Isna (2020) states that the telecommunications industry is the only industry to experience positive growth above 2 digits in this pandemic era, where in the first quarter of 2020 it grew by $9.6 \%$ and in the second quarter of 2020 it grew by $10.88 \%$. According to Setiawan (2020), there was an increase in user traffic for video streaming applications by $650 \%$, video conferencing by $275 \%$, online game applications by $81 \%$, and e-commerce by $13 \%$ during the pandemic compared to before the pandemic. However, on the other hand, the telecommunications sector also experienced a negative impact due to the decrease of people's purchasing power during the 
ongoing pandemic. In the beginning of the pandemic, the real impact on the telecommunications sector was shown by the decline in revenues from international roaming due to travel restrictions and the closure of cross-border flights. Then, the decline in revenue from the corporate segment due to cost efficiency and project delays also contributed to the decline in revenue in the telecommunications industry. In addition, the decline in basic services for telecommunications operators, especially cellular operators namely voice and Short Message Service (SMS), adds to the burden on operators facing this pandemic era. In addition to these factors, telecommunication operators are again trapped in a tariff war and are competing to offer low prices or even free to customers to access education, health applications and Covid-19 information websites. For cellular operators, another threat that needs to be considered is the change in customer behavior while moving from mobile broadband to fixed wireless broadband at home (Muttaqien, 2020).

The dynamics of changes that occur in the telecommunications sector greatly affect business actors in the telecommunications sector, especially those engaged in the sales and distribution of telecommunications products. One of the business actors in this field is the Koperasi Telkomsel (Kisel), which is a cooperative business entity formed by Telkomsel employees. More than $75 \%$ of Kisel's revenue comes from the captive market in the sales and distribution business of telecommunication products, particularly Telkomsel products. In 2018, Kisel's net profit decreased by $96.5 \%$ from the previous year due to various environmental changes, Telkomsel policies and pressure on the sales and distribution business line of this telecommunication product (Kisel, 2019).

Table 1 The business line contribution of Kisel Group 2015-2019

\begin{tabular}{|c|c|c|c|c|c|c|c|c|c|c|}
\hline \multicolumn{11}{|l|}{ (in million Rupiah) } \\
\hline \multirow[t]{3}{*}{ Business line } & \multicolumn{10}{|l|}{ Year } \\
\hline & \multicolumn{2}{|l|}{2015} & \multicolumn{2}{|l|}{2016} & \multicolumn{2}{|l|}{2017} & \multicolumn{2}{|l|}{2018} & \multicolumn{2}{|l|}{2019} \\
\hline & $\mathbf{R p}$ & $\%$ & $\mathbf{R p}$ & $\%$ & $\mathbf{R p}$ & $\%$ & $\mathbf{R p}$ & $\%$ & $\mathbf{R p}$ & $\%$ \\
\hline Sales \& Channel & 3,684 & 74.6 & 4,316 & 74.8 & 4,248 & 71.7 & 4,110 & 71.7 & 4,667 & 75.6 \\
\hline General Services & 444 & 9.0 & 507 & 8.8 & 625 & 10.5 & 552 & 9.6 & 505 & 8.2 \\
\hline Telco Infra \& Power Engineering & 385 & 7.8 & 369 & 6.4 & 388 & 6.6 & 373 & 6.5 & 361 & 5.8 \\
\hline Logistic \& Simcard Management & 69 & 1.4 & 88 & 1.5 & 119 & 2.0 & 90 & 1.6 & 67 & 1.1 \\
\hline Member Services & 31 & 0.6 & 27 & 0.5 & 32 & 0.5 & 50 & 0.9 & 26 & 0.4 \\
\hline Subsidiaries & 327 & 6.6 & 465 & 8.1 & 510 & 8.6 & 559 & 9.7 & 546 & 8.8 \\
\hline Total Revenue & 4,940 & 100.0 & 5,773 & 100.0 & 5,922 & 100.0 & 5,733 & 100.0 & 6,173 & 100.0 \\
\hline
\end{tabular}

The dependence of Kisel's business on Telkomsel has a big risk for Kisel in the long term. Realizing this risk, at the 2017 annual meeting of members it was decided that Kisel must make changes to the digital era so that it can continue to grow in the tight competition in the telecommunications industry. In the annual meeting, Kisel's shareholder created a new company vision, mission and goals and assigned Kisel's management to expand its business to markets outside Telkomsel (non-captive market). To realize the annual meeting decision, Kisel's management needs to formulate a new strategy so that it is in line with the changes that occur in the company environment.
This research aims to formulate Kisel's strategy starting from the drafting process and steps to build and develop a vision and mission, identify and analyze opportunities and threats to the company's external environment, identify internal strengths and weaknesses, set long-term strategic goals, design strategies and develop alternative strategies, as well as select priority strategies that are implemented to achieve these goals. In most research in the field of strategy, the strategy formulation stage is always prioritized before discussing the overall strategy. The strategy formulation technique used in this study is based on David's (2009) theory which divides into 3 stages of strategy 
formulation, such as the input stage, the matching stage and the decision stage.

This research is useful as an alternative thought for corporate and cooperative management in making strategy formulations, contributing to the development of strategic management knowledge, especially for companies engaged in the business of selling and distributing telecommunication products and becoming a reference for further research.

\section{METHODS}

Data collection for this research was carried out from March 2020 to December 2020 at Koperasi Telkomsel (Kisel) and its subsidiaries (PT. Kinarya Selaras Piranti, PT. Kinarya Alihdaya Mandiri, PT. Kinarya Tour \& Travel, PT. Kinarya Solusi and PT. Kinarya Utama Teknik). Meanwhile, data collection techniques and data collection information were carried out using survey methods, literature study and Focused Group Discussion (FGD).

The data used are primary and secondary data. Primary data were obtained from visit reports in the form of questionnaires, while secondary data were obtained from literature studies and internal company documents. Meanwhile, the sampling technique was using purposive sampling. This is done with the consideration that the respondents concerned have experience, expertise and are competent in their fields, consisting of internal respondents and external respondents. Respondents in this study were 31 respondents consisting of internal respondents (Management / Directors, Subsidiary Directors, General Managers and Managers) and external respondents (Telkomsel officials and competitors).

This research uses descriptive analysis to explain, summarize, reduce, simplify, organize, and present data in an orderly form so that it is easy to read, understand and conclude (Wiyono, 2001). Descriptive analysis aims to obtain an indepth picture of matters relating to the object of research. Information is presented in the form of tabulations, diagrams, graphs or images according to the results obtained (Supranto, 2003). The data processing tools and techniques used are:

1. The input stage is the stage of determining the internal and external strategic factors that influence Kisel's strategy in dealing with business changes. In the input stage, respondents are asked to write down internal and external strategic factors related to research concentration. At this stage, the Internal Factor Evaluation (IFE), External Factor Evaluation (EFE) and Internal External Matrix (IE Matrix) tables are used.

2. Matching stage is the stage to look for possible strategy options, but not to choose or determine the best strategy. At this stage, an alternative strategy is formulated based on existing strategic factors. In this study, the analysis of alternative strategies using the SWOT matrix.

3. The decision stage is the stage of making a priority sequence of strategies, which strategy will be the priority. At this stage, the determination of strategic priorities uses the Quantitative Strategic Planning Matrix (QSPM). According to David (2012) this technique serves to determine the best alternative strategy objectively. QSPM uses input cirtical success factors and weights derived from IFE, EFE, SWOT analysis and IE matrix. The results of the calculation of the QSPM method produce strategic priorities that are sorted based on the highest total attractiveness score of the alternative strategies.

\section{RESULTS \\ Koperasi Telkomsel}

The telecommunications industry, especially the cellular industry, has experienced quite high dynamics in the last 5 years, especially after the government policy requires all operators to register prepaid subscriber cards. The cellular 
operator market share is $90 \%$ dominated by 3 large operators, such as Telkomsel at $59 \%$, XL Axiata at $17,8 \%$, and Indosat at $13,4 \%$. As the operator with the largest market share, Telkomsel is the driving force for the telecommunications industry as a whole. Telkomsel's policies are very influential on competitors and partners who depend on Telkomsel for their business, especially policies on partnerships in the field of sales and distribution of their products. One of the partners that was greatly affected by Telkomsel's policy was the Koperasi Telkomsel (Kisel) as Telkomsel's Strategic Business Partner (SBP).

Kisel's business is very dependent on the captive market in Telkomsel, especially in the sales and distribution business, which accounts for $75 \%$ of Kisel's total revenue.
The large dependence of Kisel's business on Telkomsel and the occurrence of business changes towards a digital business, have made Kisel's stakeholders create guidelines and directions for change that are contained in the company's vision, mission and goals.

\section{Vision, Mission and Goals}

Facing the changing business dynamics, Kisel as a Cooperative Business Entity has goals to be achieved in the short term as well as long term goals in the form of a strategic framework which is determined and endorsed in the Member Meeting as a guideline for all Kisel stakeholders for a period of 3 years according to the tenure of the Management and Supervisors. In detail, Kisel's strategic framework for 2019 - 2021 is as follows:

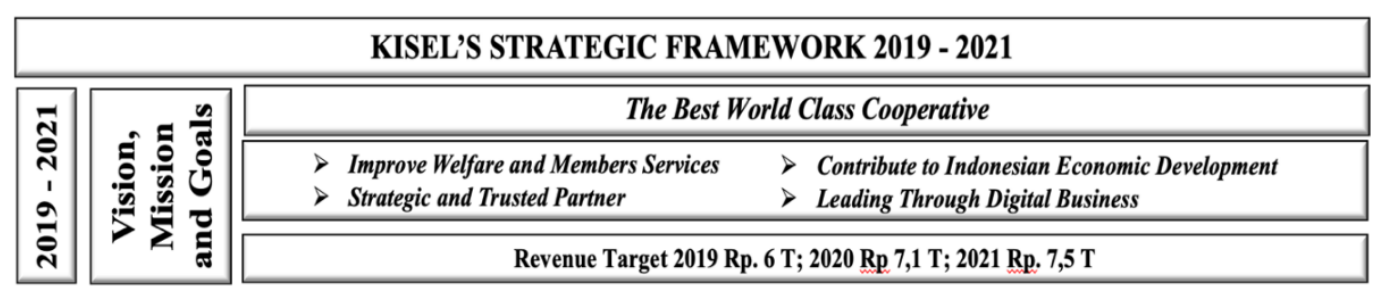

Figure 2 Kisel's Strategic Framework 2019-2021

From the picture above, it can be seen that Kisel's vision is to become the best world-class cooperative. Kisel's vision to be the best cooperative means that Kisel has the goal of being the best cooperative and becoming a cooperative that can be used as a barometer of cooperatives in Indonesia. Kisel is a strategic partner of Telkomsel which is the world's number 6 telecommunications operator and partners with world-class companies, so it is hoped that all Kisel stakeholders and business activities can reflect as a world-class company and comply with international standards. To realize this vision, it is described in four Company Missions, including:

- Improve Welfare and Member Services, means Kisel as a cooperative continues to prioritize the improvement of welfare for members on an ongoing basis through various member services. With the interests and needs of various members, all management, employees and other Kisel stakeholders are required to be able and continue to improve services according to the needs of members while still running the business.

- Strategic and Trusted Partner, means Kisel is a strategic and trusted partner for the telecommunications industry and other industries in Indonesia. Kisel's experience in the telecommunications industry, especially as a Telkomsel partner for more than 24 years, has made Kisel a competent field that can be developed in the telecommunications industry and other industries.

- Contribute to Indonesian Economic Development, means Kisel can contribute to the development of the Indonesian economy, especially in empowering the community's economy 
Mujiatno, M. Syamsul Maarif, Triyonggo Y. Formulation of strategy to face business changes in sales and distribution of telecommunication products (case study: Koperasi Telkomsel).

through cooperatives and can be used as a successful example for other cooperatives.

- Leading through Digital Business, means Kisel is expected to be at the forefront of digital business development in Indonesia through innovation and in the business of digital products.

As a business entity, the stated vision and mission is translated into the goals to be achieved in the form of revenue in 2019 amounting to 6 trillion rupiahs, in 2019 amounting to 7.1 trillion rupiahs and 2021 amounting to 7.5 trillion rupiahs.

\section{Internal Factors Evaluation (IFE)}

The identification and evaluation of internal factors is basically an examination of a company's competence, resources and position in the market. The results of this identification and evaluation are to identify and evaluate all the strengths and weaknesses of the company. Meanwhile, external identification and analysis is to determine the level of the company's response to external changes that have a major effect on Kisel's business continuity.

This internal factor evaluation was conducted to determine and evaluate all of Kisel's strengths and weaknesses. A rating consisting of a score of 4 if strength is considered a major strength and a score of 3 if strength is considered a minor strength. As for weaknesses, a score of 2 indicates a minor weakness and a score of 1 is a major weakness.

Table 2 Internal Factor Evaluation

\begin{tabular}{|l|l|l|l|}
\hline Internal Factor Evaluation & Weight & Rating & Score \\
\hline Strengths & & & \\
\hline Support for cooperative members and Telkomsel management & 0.13 & 3.80 & 0.49 \\
\hline Has all sales and product distribution channels & 0.13 & 3.73 & 0.47 \\
\hline Certified with ISO 9001 and ISO 27001 quality standards & 0.11 & 3.27 & 0.37 \\
\hline Complete variety of Telkomsel products & 0.09 & 3.13 & 0.27 \\
\hline Reliable service management & 0.12 & 3.60 & 0.43 \\
\hline Subtotal Strength Factors & 0.57 & & 2.03 \\
\hline Weaknesses & & & \\
\hline Decrease in member savings as working capital & 0.11 & 1.60 & 0.18 \\
\hline The form of a cooperative business entity is a weak image in the business world & 0.10 & 1.80 & 0.18 \\
\hline Capacity and IT systems that are not integrated & 0.13 & 1.47 & 0.18 \\
\hline The composition of Generation X is still quite large & 0.09 & 1.87 & 0.16 \\
\hline Subtotal Weakness Factors Source: Survey and FGD results (processed data) & 0.43 & & 0.71 \\
\hline Total Internal Factor Evaluation & & 2.74 \\
\hline
\end{tabular}

From the identification and evaluation of internal factors, it was found that Kisel had 5 strengths with a total strength factor value of 2.03. Support from cooperative members and management of Telkomsel is the main strength of Kisel with a value of 0.49 and product variety is the smallest strength with a value of 0.27 . Meanwhile, in terms of weaknesses, Kisel has 4 weaknesses with a value of 0.71 , where the composition of generation $\mathrm{X}$ is the main weakness with a value of 0.16 . From the table of identification and evaluation of internal factors, the IFE value is 2.74 .
External Factors Evaluation (EFE)

Table 3 Evaluation of External Factors

\begin{tabular}{|l|l|l|l|}
\hline External Factor Evaluation & Weight & Rating & Score \\
\hline Opportunities & & & \\
\hline Demography bonus & 0.09 & 2.87 & 0.25 \\
\hline $\begin{array}{l}\text { Growth of E-Commerce and } \\
\text { Digital Business }\end{array}$ & 0.12 & 3.53 & 0.42 \\
\hline The untapped rural market & 0.10 & 2.60 & 0.25 \\
\hline $\begin{array}{l}\text { Changes in consumer behavior in } \\
\text { the Digital Era }\end{array}$ & 0.11 & 3.40 & 0.37 \\
\hline $\begin{array}{l}\text { 5G (Five Generation) Network } \\
\text { Technology }\end{array}$ & 0.09 & 2.67 & 0.25 \\
\hline Subtotal Opportunity Factors & 0.50 & & 1.54 \\
\hline Threats Fixed Wireless & 0.08 & 2.33 & 0.19 \\
\hline $\begin{array}{l}\text { Growth of Frource: Survey and FGD results (processed data) } \\
\text { Broadband }\end{array}$ & 0.10 & 3.27 & 0.32 \\
\hline $\begin{array}{l}\text { Decrease in people's purchasing } \\
\text { power }\end{array}$ & 0.10 & 2.73 & 0.27 \\
\hline $\begin{array}{l}\text { Competition between operators } \\
\text { and between distributors }\end{array}$ & 0.10 & 3.33 & 0.37 \\
\hline Changes in Telkomsel's Policy & 0.11 & 3.33 & 0.36 \\
\hline Kisel's dependence on Telkomsel & 0.11 & 3.51 \\
\hline Subtotal Threats Factors & 0.50 & & 3.04 \\
\hline Total External Factor Evaluation & 1.00 & & \\
\hline \multicolumn{1}{|c|}{ Sour } & & \\
\hline
\end{tabular}


Kisel's response rate to all external factors using the EFE Matrix. The weight of each factor indicates the level of importance of the factor to other factors. The rating of each factor shows how high Kisel responds to the external factors faced. Score 4 if the company has a very good (extraordinary) response to the external environment, score 3 if the response is above average, score 2 if the response is average, and score 1 if the company's response is very low to external factors.

From the identification and evaluation of external factors, it is obtained that Kisel has 5 opportunities with a value of 1.54. The growth of e-commerce and digital business is an opportunity that Kisel responded very well compared to other opportunities. Meanwhile, from the threat side, Kisel faced 5 threats with a value of 1.51. Kisel responded well to Telkomsel's policy change with a value of 0.37 and the growth of fixed wireless broadband was responded to the lowest with a value of 0.19. Overall, the results of the identification and evaluation of external factors obtained an EFE value of 3.04 which illustrates that overall Kisel's response to changes in external factors has been very responsive.

\section{Internal and External Matrix}

Kisel's strategy based on internal and external matrices (IE Matrix) is in quadrant II with a build \& growth position with an EFE value of 3.04 and an IFE value of 2.74 . According to David (2009) the position in this quadrant shows that Kisel's position can grow and develop. Strategies that are suitable for companies with this quadrant are intensive strategies such as market penetration, market development and product development or integrative strategies such as backward integration, forward integration and horizontal integration. In this quadrant, the company is considered capable of responding to changes in the external environment and is ready internally.

From this condition, Kisel's position is a position that is ready to compete and grow in facing changes in the distribution business of telecommunication products. Kisel can penetrate and develop markets in existing and new markets. Kisel can also carry out an integration strategy through the acquisition of new partners and the acquisition of competitors.

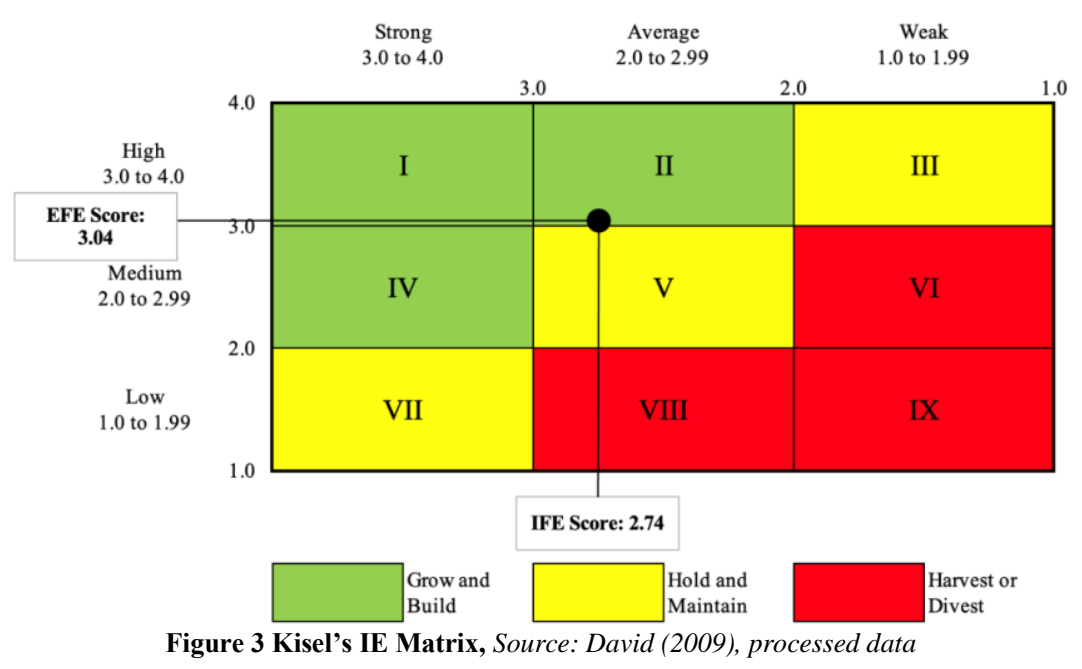

\section{Formulation of Alternative Strategies}

Based on the analysis of internal and external strategic factors, it is possible to formulate several alternative strategies for Kisel in dealing with changes in the telecommunications sales and distribution business. Based on the SWOT analysis, four alternative strategies that support each other are obtained. The four alternative strategies consist of one SO strategy, one ST strategy, one WO strategy and one WT strategy. 
Mujiatno, M. Syamsul Maarif, Triyonggo Y. Formulation of strategy to face business changes in sales and distribution of telecommunication products (case study: Koperasi Telkomsel).

\begin{tabular}{|c|c|c|}
\hline \multicolumn{3}{|c|}{ Figure 4 SWOT Matrix } \\
\hline \multirow[t]{6}{*}{ SWOT Analysis } & Strengths & Weakness \\
\hline & $\begin{array}{l}\text { Support for cooperative members and } \\
\text { Telkomsel management }\end{array}$ & Decrease in member savings as working capital \\
\hline & $\begin{array}{l}\text { Has all sales and product distribution } \\
\text { channels }\end{array}$ & $\begin{array}{l}\text { The form of a cooperative business entity is a weak } \\
\text { image in the business world }\end{array}$ \\
\hline & $\begin{array}{l}\text { Certified with ISO } 9001 \text { and ISO } 27001 \\
\text { quality standards }\end{array}$ & Capacity and IT systems that are not integrated \\
\hline & Complete variety of Telkomsel products & The composition of Generation $\mathrm{X}$ is still quite large \\
\hline & Reliable service management & \\
\hline Opportunities & SO Strategy & WO Strategy \\
\hline Demography bonus & \multirow{3}{*}{ Non captive market business expansion } & \multirow{3}{*}{$\begin{array}{l}\text { Strengthen business infrastructure and strengthen } \\
\text { digital business foundations }\end{array}$} \\
\hline $\begin{array}{l}\text { Growth of E-Commerce and Digital } \\
\text { Business }\end{array}$ & & \\
\hline The untapped rural market & & \\
\hline $\begin{array}{l}\text { Changes in consumer behavior in the } \\
\text { Digital Era }\end{array}$ & \multirow[t]{2}{*}{$\begin{array}{l}\text { (Using S1, S2, S3, S4, S5 to maximize } \\
\mathrm{O} 1, \mathrm{O} 2, \mathrm{O} 3, \mathrm{O} 4, \mathrm{O} 5 \text { ) }\end{array}$} & \multirow[t]{2}{*}{$\begin{array}{l}\text { (Minimize W3 and W4 to maximize } \mathrm{O} 1, \mathrm{O} 2, \mathrm{O} 3 \text {, } \\
\mathrm{O} 4, \mathrm{O} \text { ) }\end{array}$} \\
\hline $\begin{array}{lrrr}5 \mathrm{G} & \text { (Five } & \text { Generation) } & \text { Network } \\
\text { Technology } & & \\
\end{array}$ & & \\
\hline Threats & ST Strategy & WT Strategy \\
\hline Growth of Fixed Wireless Broadband & \multirow[t]{3}{*}{ Maintain and secure existing business } & \multirow{3}{*}{ Strengthen and develop core business } \\
\hline Decrease in people's purchasing power & & \\
\hline $\begin{array}{l}\text { Competition between operators and } \\
\text { between distributors }\end{array}$ & & \\
\hline Changes in Telkomsel's Policy & \multirow{2}{*}{$\begin{array}{l}\text { (Using S1, S2, S3, S4, S5 to anticipate } \\
\text { T1, T2, T3, T4, T5) }\end{array}$} & \multirow{2}{*}{$\begin{array}{l}\text { (Minimize W1, W2, W3 to anticipate T1, T2, T3, } \\
\text { T4, T5) }\end{array}$} \\
\hline Kisel's dependence on Telkomsel & & \\
\hline
\end{tabular}

\section{Preparation of Strategic Priorities}

\begin{tabular}{|c|c|c|c|c|c|c|c|c|c|}
\hline \multirow{4}{*}{ Critical Success Factors } & \multirow{4}{*}{$\frac{\text { Tab }}{\text { Weight }}$} & \multicolumn{8}{|c|}{ Strategy Priority } \\
\hline & & \multicolumn{8}{|c|}{ Alternative Strategy } \\
\hline & & \multicolumn{2}{|c|}{$\begin{array}{l}\text { Maintain and } \\
\text { secure existing } \\
\text { business }\end{array}$} & \multicolumn{2}{|c|}{$\begin{array}{l}\text { Strengthen } \\
\text { and develop } \\
\text { core } \\
\text { business }\end{array}$} & \multicolumn{2}{|c|}{$\begin{array}{l}\text { Strengthen } \\
\text { business } \\
\text { infrastructure } \\
\text { and strengthen } \\
\text { digital business } \\
\text { foundations } \\
\end{array}$} & \multicolumn{2}{|c|}{$\begin{array}{l}\text { Non captive } \\
\text { market } \\
\text { business } \\
\text { expansion }\end{array}$} \\
\hline & & AS & TAS & AS & TAS & AS & TAS & AS & TAS \\
\hline \multicolumn{10}{|l|}{ Strengths } \\
\hline $\begin{array}{lccc}\text { Support for cooperative } & \text { members } & \text { and } \\
\text { Telkomsel management } & & \\
\end{array}$ & 0.13 & 3.83 & 0.49 & 3.50 & 0.45 & 3.17 & 0.41 & 3.67 & 0.47 \\
\hline Has all sales and product distribution channels & 0.13 & 3.67 & 0.47 & 3.83 & 0.49 & 3.00 & 0.38 & 4.00 & 0.51 \\
\hline $\begin{array}{l}\text { Certified with ISO } 9001 \text { and ISO } 27001 \text { quality } \\
\text { standards }\end{array}$ & 0.11 & 2.67 & 0.30 & 3.33 & 0.37 & 3.17 & 0.35 & 3.50 & 0.39 \\
\hline Complete variety of Telkomsel products & 0.09 & 3.33 & 0.28 & 3.17 & 0.27 & 3.17 & 0.27 & 2.00 & 0.17 \\
\hline Reliable service management & 0.12 & 3.50 & 0.42 & 3.67 & 0.44 & 3.00 & 0.36 & 2.33 & 0.28 \\
\hline \multicolumn{10}{|l|}{ Weaknesses } \\
\hline Decrease in member savings as working capital & 0.11 & 2.67 & 0.30 & 2.50 & 0.28 & 1.83 & 0.21 & 1.50 & 0.17 \\
\hline $\begin{array}{l}\text { The form of a cooperative business entity is a } \\
\text { weak image in the business world }\end{array}$ & 0.10 & 3.83 & 0.39 & 2.33 & 0.23 & 2.17 & 0.22 & 1.67 & 0.17 \\
\hline Capacity and IT systems that are not integrated & 0.13 & 2.83 & 0.35 & 2.00 & 0.25 & 1.50 & 0.19 & 1.33 & 0.17 \\
\hline $\begin{array}{l}\text { The composition of Generation } \mathrm{X} \text { is still quite } \\
\text { large }\end{array}$ & 0.09 & 2.17 & 0.19 & 1.67 & 0.15 & 1.33 & 0.12 & 1.33 & 0.12 \\
\hline \multicolumn{10}{|l|}{ Opportunities } \\
\hline Demography bonus & 0.09 & 3.67 & 0.32 & 2.83 & 0.25 & 3.17 & 0.28 & 2.67 & 0.24 \\
\hline Growth of E-Commerce and Digital Business & 0.12 & 3.50 & 0.41 & 2.33 & 0.27 & 3.17 & 0.37 & 3.00 & 0.35 \\
\hline The untapped rural market & 0.10 & 3.00 & 0.29 & 2.17 & 0.21 & 3.17 & 0.30 & 3.50 & 0.33 \\
\hline Changes in consumer behavior in the Digital Era & 0.11 & 3.17 & 0.35 & 2.67 & 0.29 & 3.17 & 0.35 & 3.33 & 0.36 \\
\hline 5G (Five Generation) Network Technology & 0.09 & 3.17 & 0.30 & 1.67 & 0.16 & 3.33 & 0.31 & 2.83 & 0.27 \\
\hline \multicolumn{10}{|l|}{ Threats } \\
\hline Growth of Fixed Wireless Broadband & 0.08 & 2.67 & 0.22 & 2.17 & 0.18 & 3.17 & 0.26 & 1.83 & 0.15 \\
\hline Decrease in people's purchasing power & 0.10 & 2.17 & 0.21 & 2.17 & 0.21 & 2.17 & 0.21 & 1.83 & 0.18 \\
\hline $\begin{array}{l}\text { Competition between operators and between } \\
\text { distributors }\end{array}$ & 0.10 & 2.17 & 0.21 & 2.83 & 0.28 & 2.67 & 0.26 & 1.50 & 0.15 \\
\hline Changes in Telkomsel's Policy & 0.11 & 3.17 & 0.35 & 2.67 & 0.30 & 3.00 & 0.33 & 2.50 & 0.28 \\
\hline Kisel's dependence on Telkomsel & 0.11 & 3.00 & 0.33 & 2.33 & 0.25 & 2.83 & 0.31 & 3.00 & 0.33 \\
\hline Total Score & & & 6.18 & & 5.33 & & 5.49 & & 5.07 \\
\hline
\end{tabular}

The determination of strategic priority is carried out by the QSPM method, which is one of the methods commonly used in making a priority order of various choices 
which can then be used to make a decision. The results of calculations using the QSPM method obtained the priority of the Kisel strategy as follows:

1. Maintaining and securing the existing business is the first priority strategy with a total attractiveness score of 6.18 .

2. Strengthening business infrastructure and strengthening digital business foundations are the second priority strategy with a total attractiveness score of 5.49 .

3. Strengthening and developing the core business is the third priority strategy with a total attractiveness score of 5.33.

4. The expansion of non-captive market business is the last priority strategy with a total attractiveness score of 5.07.

With this strategic priority, it can be used as a guideline for which strategy takes precedence over other strategies or which strategies are currently needed to achieve short-term goals. However, it does not mean that a strategy with a higher priority can eliminate other strategies, but that all strategies must be able to go hand in hand to achieve the overall goals of the company.

\section{CONCLUSIONS}

From the evaluation of internal and external factors, it is obtained that Kisel has five strengths with a value of 2.03 , four weaknesses with a value of 0.71 , five opportunities with a value of 1.54 and 5 threats with a value of 1.51 . So that in total the IFE value is 2.74 and EFE is 3.04 which in the IE matrix is in the position of build \& growth with an intensive strategy. Kisel is ready to compete and grow in the face of changes in the distribution business of telecommunication products.

Based on the SWOT analysis, there are four alternative strategies for Kisel to face changes in the business of selling and distributing telecommunications products, namely: SO strategy (non-captive market business expansion), ST strategy (maintaining and securing existing business), WO strategy (strengthening business infrastructure and business foundations. digital) and the WT strategy (strengthening and developing the core business).

By using the Quantitative Strategic Planning Matrix (QSPM) decision-making method, strategic priorities are obtained: maintaining and securing the existing business is the first priority strategy with a value of 6,18 , strengthening business infrastructure and strengthening digital business foundations becomes the second priority strategy with a value of 5,49, strengthening and developing the core business is the third priority strategy with a value of 5,33 and expansion of the noncaptive market business is the last priority strategy with a value of 5,07.

\section{Acknowledgement: None}

\section{Conflict of Interest: None}

\section{Source of Funding: None}

\section{REFERENCES}

1. Aji, M.S. 2017. Formulasi Strategi Pengembangan Bisnis Model Mikro Bank X. [Thesis]. Bogor (ID): Institut Pertanian Bogor.

2. Ambodo, P.K. 2019. Formulasi Strategi Bisnis PT Robotaqua Indonesia. [Thesis]. Bogor (ID): Institut Pertanian Bogor.

3. Azmadahadid, M. 2019. Formulasi Strategi Perbaikan Kinerja Perusahaan Properti PT XYZ Pasca Akuisisi. [Thesis]. Bogor (ID): Institut Pertanian Bogor.

4. David, F.R. 2009. Strategic Management (Concepts and Cases). Ed ke-8. New Jersey (US): Prentice.

5. David, F.R. 2011. Strategic Management Manajemen Strategis Konsep. Edisi 12. Jakarta (ID): Salemba Empat.

6. David, F.R. 2012. Strategic Management Manajemen Strategis Konsep. Jakarta (ID): Salemba Empat.

7. Ermaya, S.K. 2019. Strategi Pengembangan Koperasi Dengan Analisis SWOT. [Journal]. Jakarta (ID). Jurnal Ekonomi dan Bisnis Volume 6 Nomor 1, 2019: Universitas Pembangunan Nasional Veteran. 
Mujiatno, M. Syamsul Maarif, Triyonggo Y. Formulation of strategy to face business changes in sales and distribution of telecommunication products (case study: Koperasi Telkomsel).

8. Ernawati, E.E. 2017. Strategi Koperasi Simpan Pinjam Jasa (Kospin Jasa) dalam Pengembangan Usaha [Essay]. Semarang (ID): Universitas Negeri Semarang.

9. Gunawan, A.I. 2019. Formulasi Strategi Distributor Alat dan Mesin Pertanian (Studi Kasus PT Bina Pertiwi. [Thesis]. Bogor (ID): Institut Pertanian Bogor.

10. Hage, S.G. 2016. Formulasi Strategi untuk Meningkatkan Daya Saing White Tea (Studi Kasus: Pusat Penelitian Teh dan Kina Gambung, Jawa Barat. [Thesis]. Bogor (ID): Institut Pertanian Bogor.

11. Heryadi, D. 2015. Transformasi Bisnis Koperasi Menuju Model Bisnis Korporasi (Studi Kasusdi Koperasi Indosat). Jakarta (ID). Journal Applied Business and Economics. Vol. 1 Nomor. 4: Universitas Indraprasta PGRI.

12. Isna. 2020. Pasar Digital Berkembang Pesat Saat Pandemi Covid-19. Di dalam: Untung $S$, redaktur. [Internet]. Jakarta (ID) : Portal Berita Info Publik [downloaded 2020 Oktober 20]. Available at: http://infopublik.id/kategori/nasionalekonomi-bisnis/

13. Itang. 2016. Badan Usaha Koperasi dan Badan Usaha Non Koperasi (Studi Komparatif). [Journal]. Banten (ID). Jurnal Ekonomi Keuangan dan Bisnis Islam Volume 7 Nomor 1 Januari - Juni 2016: IAIN Sultan Maulana Hasanuddin.

14. Johan, A.W. 2018. Formulasi Strategi Peningkatan daya Saing Hotel Individu. [Thesis]. Bogor (ID): Institut Pertanian Bogor.

15. Kementerian Hukum \& HAM. UndangUndang Republik Indonesia Nomor 25 Tahun 1992 Tentang Perkoperasian. 1992. [Internet]. [downloaded 2020 November 3]. Available at: https://www.dpr.go.id/dokjdih/document/uu 1783

16. Koperasi Telekomunikasi Seluler. Laporan Tahunan Pengurus dan Pengawas pada Rapat Anggota Tahunan Kisel Tahun Buku 2019. 2020. [Internal Document]. Jakarta.

17. Muslim, M. 2017. Membangun Visi Perusahaan. Jurnal ESENSI Institut Bisnis Nusantara. 20:3.

18. Muttaqien, Z. 2020. Ada Covid-19, Operator Telekomuniaksi Diuntungkan? Di dalam: Kolom Opini. [Internet]. Jakarta (ID): Portal Berita Indotelko.com [downloaded 2020 Juni 21]. Available at: https://www.indotelko.com/read/158673037 5/covid-19-operator

19. Nawawi, H. 2005. Manajemen Strategik. Yogyakarta: Gadjah Mada Press.

20. Pakaya, A.R. 2017. Koperasi Indonesia: Manajemen Kinerja Koperasi. Yogyakarta (ID): Zahir Publishing.

21. Pearce JA, Robinson JRB. 2008. Manajemen Strategik: Formulasi, Implementasi dan Pengendalian. Jakarta (ID): Binarupa Aksara.

22. Porter, M.E. 1998. From Competitif Advantage to Corporate Strartegy. Boston (UK): Harvard Business Pr.

23. Rangkuti, F. 2009. Analisis SWOT Teknik Membedah Kasus Bisnis. Jakarta (ID): PT. Gramedia Pustaka Utama.

24. Rohmat, A.B. 2015. Analisis Penerapan Prinsip-Prinsip Koperasi Dalam UndangUndang Koperasi. [Internet]. Semarang (ID): Portal Berita LPPM-Unissula.com, Jurnal Pembaharuan Hukum Volume II No 1 Januari - April 2015 [downloaded 2020 Desember 15]. Available at: http://lppmunissula.com/jurnal.unissula.ac.id/index.php /PH/article/view

25. Ropke, J. 1995. Kewirausahaan Koperasi: Dinamika Kewirausaahan dan Pengembangan Dalam Organisasi Swadaya. Bandung (ID): UPT Penerbitan IKOPIN.

26. Rukmana, Y. 2014. Formulasi Strategi Transformasi pada Lembaga Amil Zakat Nasional Dompet Duafa [Thesis]. Bogor (ID): Institut Pertanian Bogor.

27. Sampurno. 2013. Manajemen Stratejik: Menciptakan Keunggulan Bersaing Yang Berkelanjutan. Yogyakarta (ID): Gadjah Mada University Press.

28. Sastrawidjaja, HMS, Adam, Richard C. 2015. Langkah Menuju Konglomerasi Koperasi di Indonesia. [Journal]. Bandung (ID): Portal Berita jurnal.unpad.ac.id, Padjadjaran Jurnal Ilmu Hukum Volume 2 Nomor 2 [downloaded 2020 Desember 15]. Available at: http://jurnal.unpad.ac.id/pjih/article/view/73 34

29. Setiawan I, Resa DP, Sabrina I, Rika N, Keke G, Ramadhan MH. 2020. How to Manage Traffic Explotion and Gain User Conversion during the Pandemic: Telin Inssight. [Internet] 2017. Jakarta (ID): Portal Berita Telin.net; [downloaded 2021 Januari 16]. Available at: https://www.telin.net/id/customer- 
Mujiatno, M. Syamsul Maarif, Triyonggo Y. Formulation of strategy to face business changes in sales and distribution of telecommunication products (case study: Koperasi Telkomsel).

portal/whitepapers/white-paper-telininsights-webinar-series-1--how-to-managetraffic-explosion-and-gain-user-conversionduring-the-pandemic

30. Supranto, J. 2003. Metode Riset Aplikasi Dalam Pemasaran. Edisi Revisi Ketujuh. Yogyakarta: Rineka Cipta.

31. Umar, H. 2003. Strategic Management in Action. Jakarta (ID): Gramedia Pustaka Utama.

32. Wheleen TL, Hunger. 2010. Strategic Management and Business Policy. Ed ke-9. New Jersey (US): Prentice Hall International.
33. Wiyono, B.B. 2001. Statistik Pendidikan: Buku Bahan Ajar Mata Kuliah Statistik. Malang (ID): $\quad$ FIP Universitas Muhammadiyah.

How to cite this article: Mujiatno, M. Syamsul Maarif, Triyonggo Y. Formulation of strategy to face business changes in sales and distribution of telecommunication products (Case Study: Koperasi Telkomsel). International Journal of Research and Review. 2021; 8(7): 126-135. DOI: https://doi.org/10.52403/ijrr.20210717 